\title{
DESTRUCTIVE WAVE OVERTOPPING TESTS ON GRASS COVERED LANDWARD SLOPES OF DIKES AND TRANSITIONS TO BERMS
}

\author{
Gosse Jan Steendam ${ }^{1}$, Jentsje W. van der Meer ${ }^{2}$, Bianca Hardeman ${ }^{3}$, André van Hoven ${ }^{4}$ \\ In 2009 tests have been performed at the Afsluitdijk, the closure dike of Lake IJssel in the Netherlands. This dike has \\ a sand core covered by layers of clay and boulder clay, and a grass cover. In 2010 succeeding tests were performed at \\ a river dike near Zwolle. This dike was a sand dike with a grass cover. In all of these tests research was performed on \\ the behaviour of the grass cover on the landward slope of the dikes. Furthermore, the influence on erodibility of the \\ grass cover caused by damage of the grass cover by mice, moles or other influences like tractor tracks were \\ investigated. Also the influence of obstacles or other elements, which may be present at dikes, was part of the \\ investigations (tree, stairs, fence, maintenance road). It was observed that all of these influences are to some extent \\ contributing to a decrease of the resistance against failure.
}

Keywords: dikes; levees; prototype tests; overtopping; wave overtopping simulator; grass erosion

\section{INTRODUCTION}

In the past a lot of effort was spent to establish knowledge on the hydraulics of wave overtopping on dikes, levees, seawalls and embankments. The erosive effect of these overtopping waves on dikes, embankments or levees, however, was not investigated much. Therefore, strength of grass covered landward slopes is not well known. The reason for the lack of research is mainly that it is very difficult or even impossible to scale down all parameters involved in the geometry (clay, grass) at the landward slope of dikes. Also it is not easy and quite costly to bring a real dike to a laboratory, which should be done in pieces, introducing (possible) failure at the connections between grass and clay blocks. With the development of the Wave Overtopping Simulator (Van der Meer et al. 2006, 2007) it is now possible to perform field research on the resistance against erosion of grass covered slopes.

First tests were performed within the ComCoast project (Van der Meer et al. 2007, Akkerman et al. 2007, www.comcoast.org). In 2008 further comparative destructive field tests on differently managed and maintained grass covers were performed (Steendam et al., 2008, Van der Meer et al., 2008, 2009). In these tests it was found that transitions from slopes to horizontal berms seemed to be weak parts in the configuration of the dike. In the current guidelines for safety assessments for dikes it is mentioned that objects on the slopes and crest may be of significant influence on the stability of the cover of the dike. The basis for these statements in the guidelines is not well known. The influence of objects present in or on real dikes on the stability of crass covers has never been tested in a range. In previous tests a small $5 \mathrm{~cm}$ wide pole, placed during the experiments, was tested. It turned out that pole did not have a significant effect on the erodibility of the grass covered slope (Steendam et al. 2008). Therefore, in 2009 tests have been performed on the Afsluitdijk (Figure 1) with the objective, next to evaluation of the performance of the grass cover on the slope to loads due to overtopping, to monitor the behaviour of the grass cover on the toe (transition from slope to horizontal) of the dike. With this second objective a series of tests have been performed on a section with a grass covered transition and a section with a transition to a parking lot. A third objective of these tests was to evaluate the performance of a staircase on the landward slope. Staircases are used to create a means for public access to the dike to have a view on the sea in front of the dike. Also staircases are used as access for inspection of the dikes.

\footnotetext{
${ }^{1}$ INFRAM b.v., P.O Box 16, 8316 ZG Marknesse, The Netherlands, Gosse.Jan.Steendam@infram.nl

${ }^{2}$ Van der Meer Consulting, b.v., P.O. Box 423, 8440 AK Heerenveen, The Netherlands, jm@vandermeerconsulting.nl

${ }^{3}$ Directorate-General for Public Works and Water Management, Centre for Water Management, P.O. Box 17, 8200 AA, Lelystad, The Netherlands, Bianca.Hardeman@rws.nl

${ }^{4}$ Deltares, P.O Box 177, 2600 MH Delft, The Netherlands, Andre.vanHoven@Deltares.nl
} 


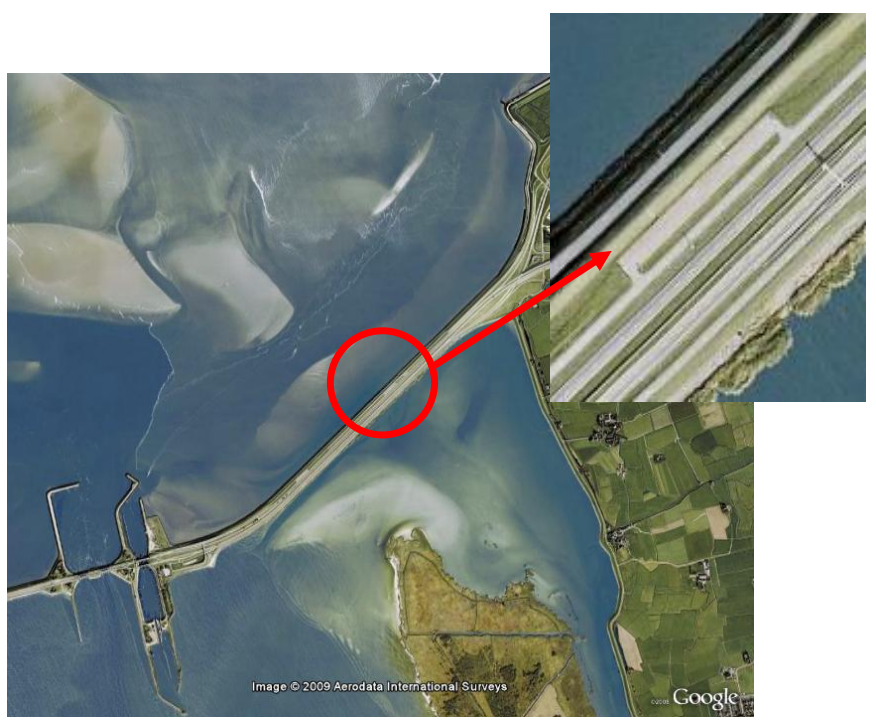

Figure 1. Overview of test location 2009 at Afsluitdijk in the Netherlands

Until 2009 field tests were performed at dikes with a sand content up to $70 \%$ in the cover clay layer (or complete clay dike). In 2010 a new series of tests has been performed at a sand dike. This sand dike is located along the river Overijsselse Vecht (Figure 2). The sand content of the top layer was measured to be between $88 \%$ and $94 \%$ with a lutum content of $2-4 \%$. The grain size distribution of the top layer did not differ significantly from the dike core; however, the top layer could be distinguished by a brown coloration probably due to humus and ferroxides. For these tests the objective again was observation of the behaviour and performance of the grass cover on the landward slope. Next to this a test section with a tree on the landward plain was investigated. A third test section contained a management road crossing the dike. This maintenance road consisted of large open concrete bricks that allow for grass growth. These bricks are used for esthetical reasons. The dike still looks green but provides a solid base for maintenance vehicles like tractors.

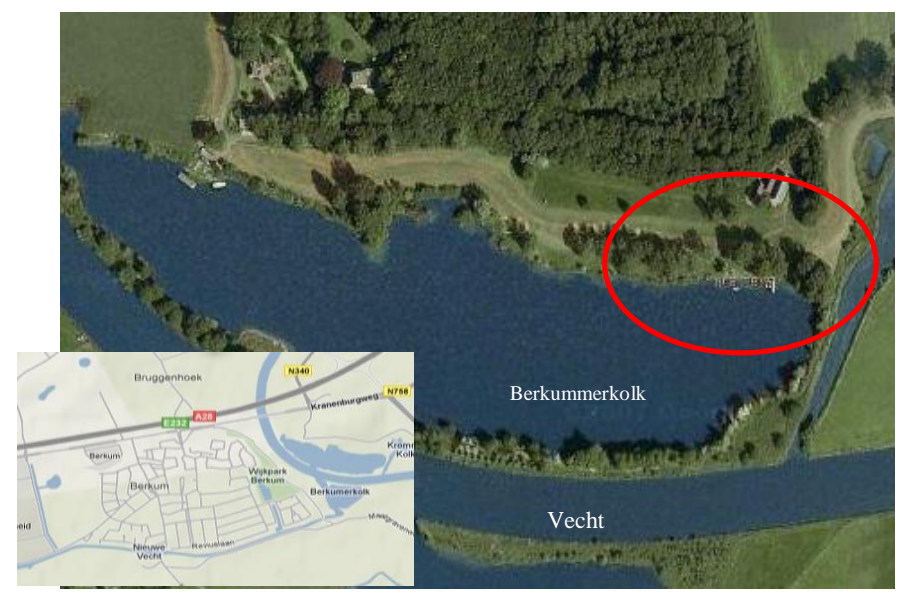

Figure 2. Overview of test location 2010 at the Vecht in the Netherlands

Up to 2009 all tests were performed using the same hydraulic conditions. The overtopping waves were calculated using a significant wave height $\mathrm{H}_{\mathrm{s}}$ of $2 \mathrm{~m}$. The wave steepness $\mathrm{s}_{\mathrm{op}}$ was taken to be $4 \%$. To calculate the overtopping wave volumes a seaward slope 1:4 was taken. These conditions represent typical extreme conditions for the Dutch coast. As they are typical for the Dutch coast they are not representative for extreme conditions along Dutch river dikes. Also locations along the Dutch sea coast exist with even more severe hydraulic conditions. During the evaluation of the tests up to 2009 it was concluded that the influence of more or less severe conditions had to be investigated. The mean overtopping rate did not change with these altered conditions. The change is in the amount, volume and frequency of individual overtopping waves; see also Van der Meer et al., 2010.

As a result tests were performed in 2010 with wave heights $H_{s}=1 \mathrm{~m} ; 2 \mathrm{~m}$ and $3 \mathrm{~m}$. The wave steepness was not changed, neither the representative seaward slope angle. 
All the tests mentioned above were performed as part of the long term project Overtopping and Strength of Grass Covers within the program Strength and Loads on Flood Defences (SBW) from the Dutch Ministry of Transport, Public Works and Water Management.

\section{SETUP OF TESTS 2009 AND 2010}

The Afsluitdijk is located in the northern part of the Netherlands. At the test location three different test sections were available. At the Vecht dike four test sections were investigated. All had different characteristics. The test sections can be described as follows:

- Afsluitdijk:

1. a grass covered landward slope of about $8 \mathrm{~m}$ long, which at the lower end made a transition into a horizontal grass covered berm;

2. a grass covered landward slope of $8 \mathrm{~m}$ long with a transition to a horizontal parking lot, covered with small pitched stone bricks.

3. a grass covered slope with a concrete staircase and a fence on the landward slope.

- Vecht dike

1. a grass covered slope with a maintenance road across the slope

2. a grass covered slope with a tree on the berm

3. a grass covered slope tested at moderate conditions $\left(\mathrm{H}_{\mathrm{s}}=1 \mathrm{~m}\right)$

4. a grass covered slope tested at severe conditions $\left(\mathrm{H}_{\mathrm{s}}=3 \mathrm{~m}\right)$

All test sites have been tested with the Wave Overtopping Simulator (Van der Meer et al. 2006, 2008). Overtopping discharges of 0.1 to $75 \mathrm{l} / \mathrm{s}$ per meter dike were washed down the landward slopes of the dikes, giving individual overtopping volumes in a wave up to $5.5 \mathrm{~m}^{3}$ per $\mathrm{m}$ width. These discharges are released in a manner that the real distribution of individual overtopping waves is realized. The condition of the grass cover was monitored intensively. All relevant strength parameters such as root systems of the grass, soil characteristics and thickness of the cover layer were investigated.

\section{Investigations on root system}

The resistance against erosion of a grass cover depends highly on the vitality of the grass cover and the condition of the root system of the grass cover, consisting of substrate and roots. In the investigations also development during winter conditions was investigated. The quality of the grass cover is determined by means of measuring the distribution of the amount of roots over depth. The quality is then scored according to the prescribed Dutch guidelines for safety assessments of dikes (VTV2006). The overall score for the quality of the grass cover on the test locations was "good".

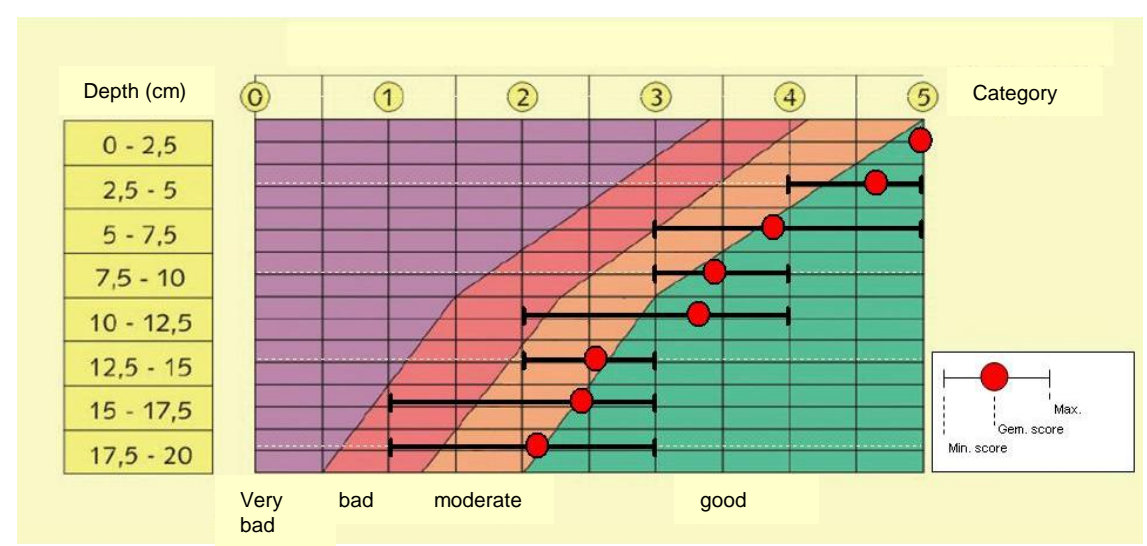

Figure 3. Average score according to VTV2006 of quality of the root system, February 2009

Figure 3 shows that the root system at the Afsluitdijk was in a good condition (average number of roots, represented by categories, in each depth segment in the green area). Also it was found that the quality during winter did not decrease. With that it has to be noticed that the winter of 2008 / 2009 was very moderate with temperatures just incidentally below freezing point. Nevertheless, also during other winters it has been seen that the root system stays in fairly good condition in the Dutch climate. The same results were found at the Vecht dike. 


\section{Soil investigations}

Next to the grass investigation also soil investigations have been made (Deltares, 2009 and 2010). Field investigations as well as laboratory investigations have been made. In accordance with VTV2006 the resistance of the clay against erosion can be classified with the yield value $W_{i}$, the plasticity index $I_{p}$ and the sand content. With these parameters the clay present at the Afsluitdijk is classified as being low erosion resistant. The Vecht dike was completely a sand dike.

\section{Tests setup}

The overtopping Simulator was placed on the seaward (or river) slope of the dike, see Figures 4 and 5. The outflow of the Simulator is placed just in front of the crest. In this way the crest can be tested as well. The inflow of the simulator is managed by a large frequency regulated electric submersible pump capable to deliver a discharge of over $1,800 \mathrm{~m}^{3} /$ hour. At the Afsluitdijk the pump was placed in a ditch at the landward side of the dike, created for this purpose. The ditch was filled by sea water by means of a smaller pump. The water released from the overtopping simulator flowed back into the ditch. At the Vecht dike the inflow was taken from the river. The outflow was collected in a container which was dug into the ground. Power was supplied by a diesel generator and the overtopping simulator was operated by means of hydraulics operated by a PLC. The PLC was fed by steering files containing every individual wave and time to release these waves. In the steering files all waves from the distribution were randomized causing release of random volumes from the simulator.

Each of the test sections was $4 \mathrm{~m}$ wide. On the sides of the sections wooden plates were mounted to guide the released water from the overtopping simulator. At the landward toe of the dike a measurement cabin was placed on a wooden cart.

All tests were logged on video. In contrast with previous tests now a special test section was reserved for hydraulic measurements.

In this test on hydraulic measurements front velocities, flow depths and air content of different overtopping wave volumes were measured with several devices. To assess the reproducibility of the measurements each volume was simulated three times. Also the tests have been repeated with different locations of the instruments. The test

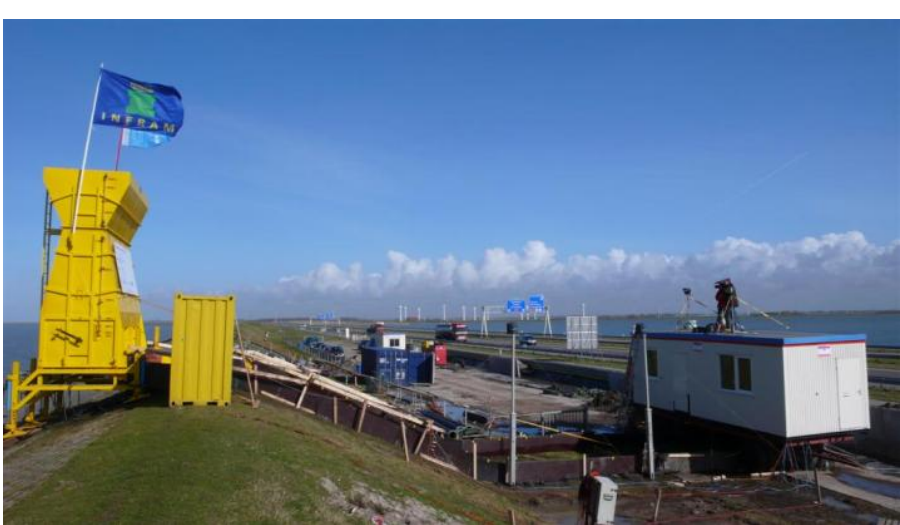

Figure 4. Set up of overtopping tests at Afsluitdijk

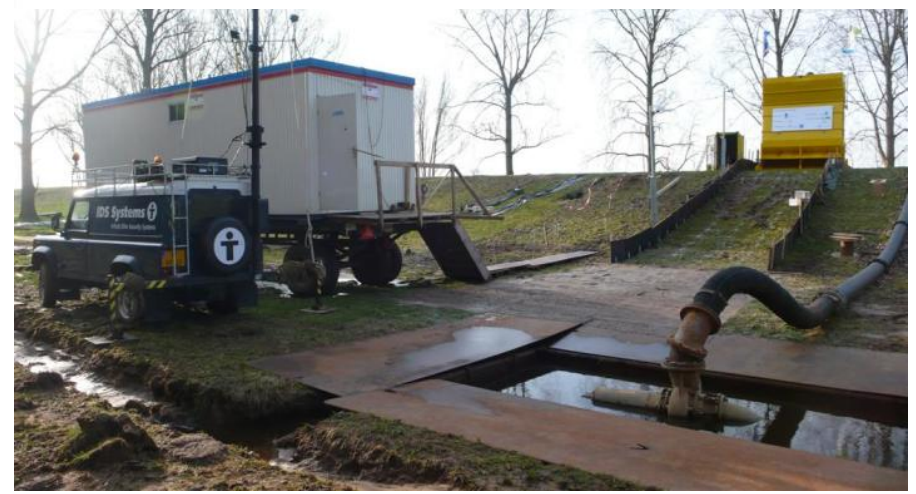

Figure 5. Set up of overtopping tests at the Vecht dike series consisted of the volumes: 200, 400, 600, 800, 1000, 2000, 30004000 and 5000 1/m.

Tests until 2009 were all performed using fresh or brackish water. To assess the possible influence of salt water on front velocities, flow depths and air content measurements were performed at the Afsluitdijk with fresh water $\left(1000 \mathrm{~kg} / \mathrm{m}^{3}\right)$ and salt water $\left(1030 \mathrm{~kg} / \mathrm{m}^{3}\right)$. Fresh water was taken from a pond not far from the location. The first test was done using fresh water. For the second test series salted water was made. To increase the salinity, over 33 tons of salt suspension was added (ca. 22.5\% $\mathrm{NaCl}$ ). A total of 8 tests with fresh and salted water were performed. Results of the hydraulic measurements are described by Van der Meer et al. 2009 and 2010.

During the regular tests in sections 1 to 3 the salinity of the water ranged between 1005 and 1009 $\mathrm{kg} / \mathrm{m}^{3}$ and was directly taken from the Wadden Sea. This salinity of the sea water was quite low probably because there is a fresh water outlet near the test location on the Afsluitdijk. 


\section{Flow depth of the water tongue}

To measure the flow depth of the water tongue caused by an overtopping wave on the landward slope wave gauges and 'surf boards' were used.

Wave gauges. Wave gauges measure the thickness of the water layer excluding the air content. The wave gauges consisted of 2 wires with a parting distance of $50 \mathrm{~mm}$. A sensor measures alterations in resistance caused by the inundation.

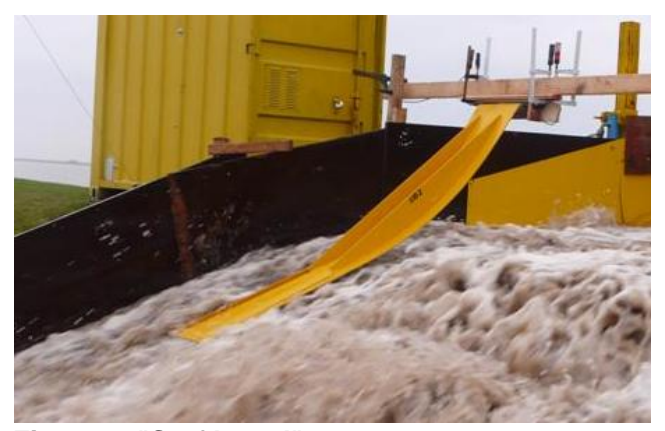

Figure 6. "Surf board"

Surf board. Next to the measurements with the wave gauges the layer thickness also was measured by a surfboard (Figure 6). This surf board is an alternative developed by Infram for the measurements by the wave gauges. The prototype was tested at previous wave overtopping tests (Steendam et al 2008). As compared to the previous tests the prototype used at the Afsluitdijk was further developed. With experiments in the dredging flume from Deltares the prototype was optimized in shape and stiffness. Also the height of the hinging point has been optimized (Ooij and Hull, 2009).

Prior to each measurement session the surfboard was recalibrated. The movement of the surf board during the tests created a continuous record representing the flow depth including air (Figure 7).

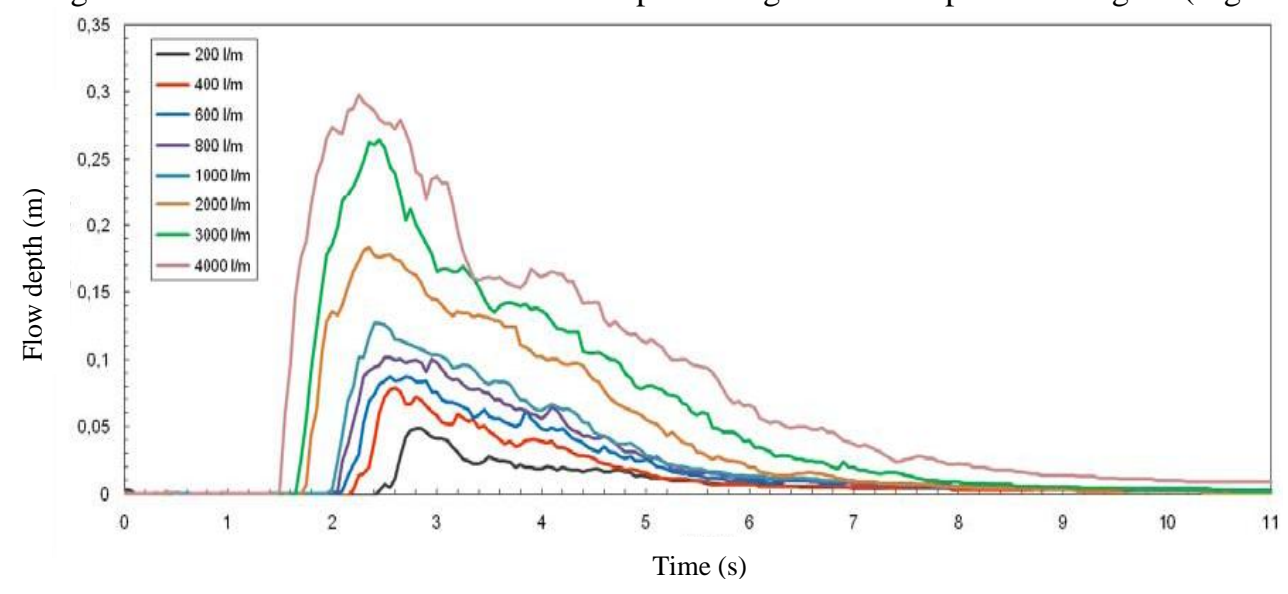

Figure 7. Example flow depths, recorded with the surf board

Figure 7 shows that waves tend to stretch. Larger overtopping waves have a longer duration. Also from the measurements it was found that larger overtopping waves have higher front velocities. From the comparison between the use of salt water and fresh water it could be concluded that salt water gives slightly higher flow depths (Figure 8).

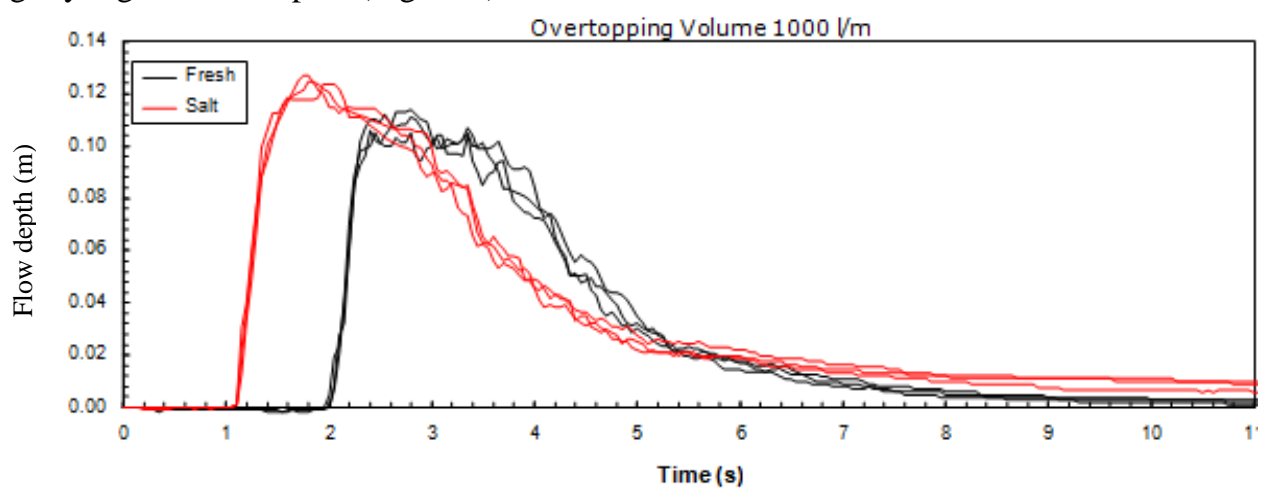

Figure 8. Difference in Flow depths between fresh and salt water (Overtopping volume $1000 \mathrm{l} / \mathrm{m}$ )

After the tests at the Afsluitdijk it was concluded that the surf board served its purpose very well. Therefore, at the Vecht dike five surf boards were used to get an impression of the development of the overtopping flow of water over the slope. Also a paddle wheel for measuring velocities was installed in two wave boards as well as one in the surface of the slope. A full description and analysis of these measurements can be found in Van der Meer et al. 2010. 
Front velocity. The front velocities at the Afsluitdijk were hind casted by means of video images. All overtopping volumes had been captured by a high speed camera (50 frames per second). After the tests with the help of pre defined marked referential spots on the slope the front velocities were analyzed. From the analysis's it is found that by means of a high speed camera it is very well possible to determine the front velocity of overtopping waves. It was found that:

- The front velocity increases with higher overtopping volumes;

- The front velocity with large volumes tends to reach a maximum;

- The front velocity is most likely the same for salt and fresh water;

Erosion. Erosion on the landward slope and the landward toe caused by the overtopping water was monitored during all tests by video imaging and photographs. In addition the erosion landward from the toe was measured every hour by hand. For this purpose the tests were shortly interrupted and the water in the erosion holes was pumped out to get a clear view on the erosion.

\section{TESTS}

At the Afsluitdijk four overtopping tests were performed and at the Vecht dike five (including hydraulic measurements). All tests were performed according the program with 1, 10, 30, 50 and 75 1/s per $\mathrm{m}$. Each test lasted for 6 hours. The 1 1/s per $\mathrm{m}$ test was accelerated 5 times resulting in a duration of 72 minutes. The hydraulic measurements were performed with a limited number of waves in a fixed sequence, see Van der Meer 2009.

\section{RESULTS}

\section{Erosion at the slope}

The erosion of the grass covered slopes on all three test sites (excluding the test site for hydraulic measurements) at the Afsluitdijk developed more or less in the same manner. It started with a small initial damage on the slope and then developed on downward, ripping off the grass cover. The width of the damage evolved from $0.1 \mathrm{~m}$ to several decimetres downward. In some cases two of these damages developed parallel and merged at a certain time. The initial depth of the damage ranged between 0.05 $\mathrm{m}$ and $0.1 \mathrm{~m}$. The eroded surface increased during the tests substantially while the depth of the damage hardly changed. Overall it can be concluded that erosion at the Afsluitdijk in the appearance of ripping off the grass cover to a depth of 0.05 to $0.1 \mathrm{~m}$ occurred with large overtopping waves. Large surfaces of the grass cover disappeared in this way during the tests.

At the Vecht dike similar initial damages occurred (not considering damages occurring at objects). Starting at an irregularity like a animal hole (moles) the grass cover tore off at a depth of 0.05 to $0.1 \mathrm{~m}$. The difference was that the damage at the Vecht dike was ongoing, resulting in failures of the dike after some time. But also here the remaining rooted top layer showed quite some strength, despite of the fact that it was $90 \%$ sand.

In both cases it was concluded that the top layer was "cemented", possibly by the root system, resulting large erosion resistance when the grass cover disappeared. Both erosional clay and sand are not erosion resistant, but with a root system it was. This conclusion should be validated by more research.

\section{Erosion at the toe}

The erosion at the Afsluitdijk of the horizontal part landward of the landward toe of the dike developed in the same way as the slope did, with the exception of the development of the depth. Where the erosion did not deepen at the slope, at the toe the erosion was on going. But even after full testing the erosion depth of the scour hole was limited to about $0.4 \mathrm{~m}$. At the Vecht dike the transition from slope to berm was rounded causing a gentle flow parallel to the surface of the dike. As the flow was not jetted into the berm no damage was initiated at the toe of the dike.

In the next section the results of each test is described in more detail.

\section{Test (Afsluitdijk) A1: grass covered slope with transition to grass covered berm}

The outflow of the Simulator was located approximately $0.5 \mathrm{~m}$ seaward of the landward inner crest. This landward inner crest point is the zero point for all length measurements. Relative to this point the landward toe of the dike was at $7.8 \mathrm{~m}$ measured along the slope. From the toe a $6 \mathrm{~m}$ wide berm started.

The landward slope was covered with short vegetation that almost entirely consisted of grasses. There were hardly any herbs present and locally some thistles.

Results of test series 1. In the first session of two hours with 10 1/s per m initial damage occurred at a small irregularity at the toe of the dike. A small part of the grass cover was torn off creating a hole of about $0.75 \mathrm{~m}^{2}$ with a depth of $0.1 \mathrm{~m}$ (Figure 9). 


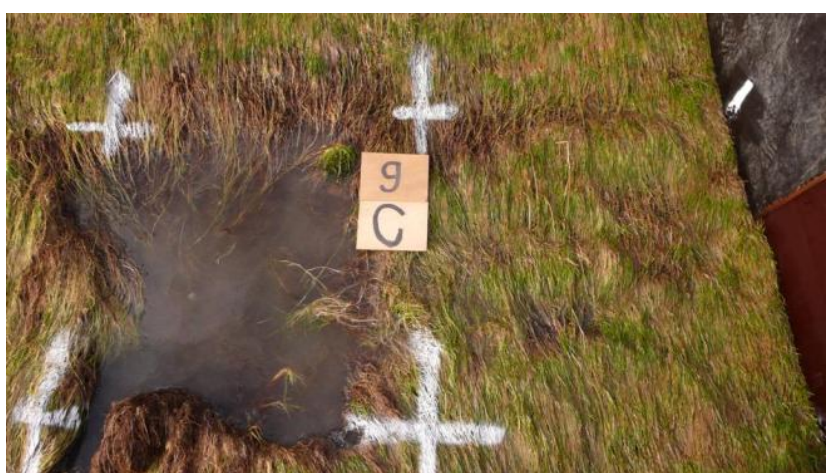

Figure 9. Initial damage at toe of section $1\left(0.75 \mathrm{~m}^{2}\right.$; depth 0.1 m)

resistant.
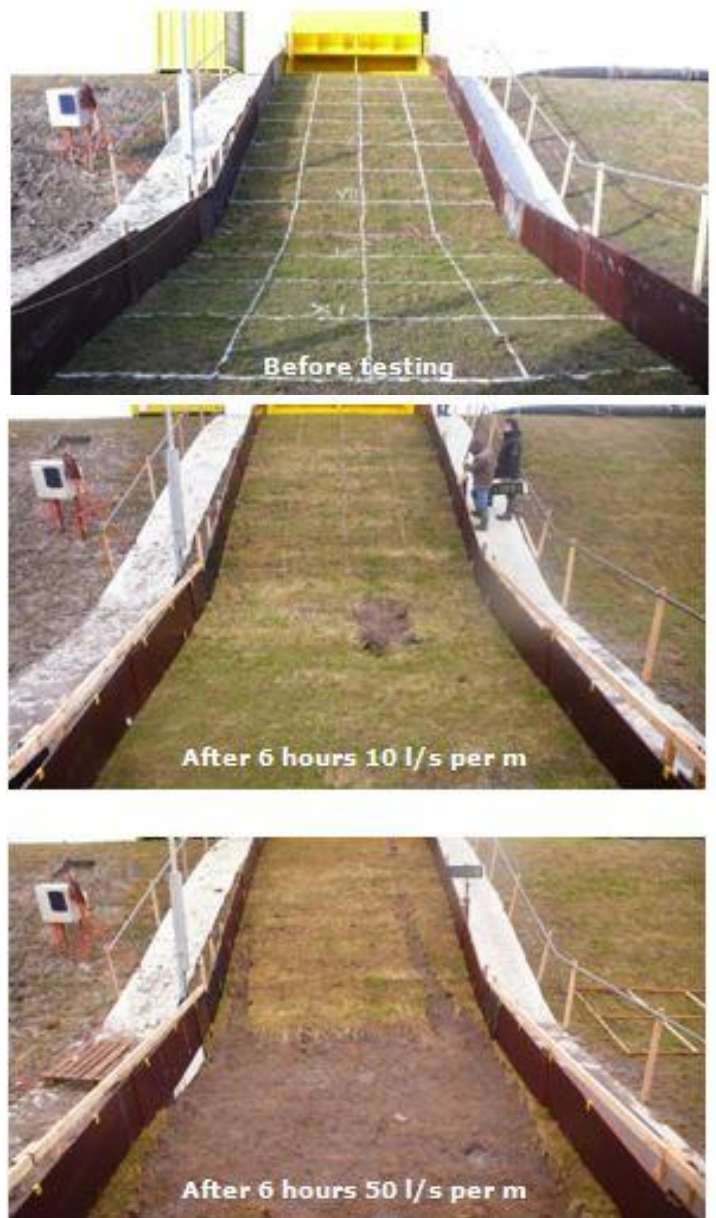

Figure 10. Development of damages in test section 1
During $30 \mathrm{l} / \mathrm{s}$ per $\mathrm{m}$ the damage at the toe developed gradually to over $10 \mathrm{~m}^{2}$ and at $501 / \mathrm{s}$ per $\mathrm{m}$ the complete grass cover at the toe had disappeared. However the depth of the damage did not change much.

During the last test $(75 \mathrm{l} / \mathrm{s}$ per $\mathrm{m})$ the damages developed further in length and width but did not lead to failure of the dike. Figure 10 gives an overall view of the development of the damages over the test series in test section A1.

It was concluded that the grass cover failed easily, but the remaining top layer of rooted clay was remarkably erosion
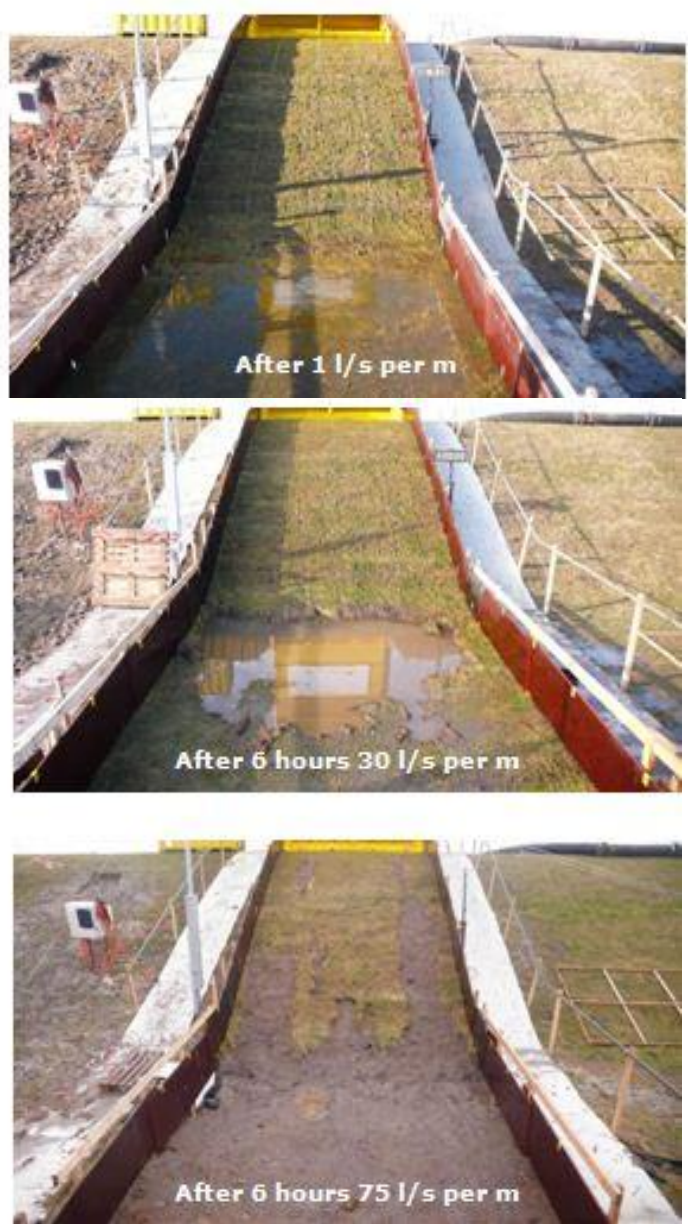

\section{Test (Afsluitdijk) A2: Grass covered slope with a transition to a parking lot}

The grass on the crest and the landward slope was in a good condition and was even in length. In this test section some markings of tires of mowing vehicles were present. One obvious spot was a deep tire track. At the location of the for this test removed fence a small ridge was present with high and rough grass. In this ridge traces of mice activity was clearly present (tracks and holes). Between the removed fence and the parking lot a $0.7 \mathrm{~m}$ wide strip with high and rough grass was present edging to a small gutter with bricks on clay in front of a concrete curbing adjacent to the pitched bricks of the parking lot. 
Results of test series A2. At 1 1/s per m small initial damage occurred at the tire track. In the following $10 \mathrm{l} / \mathrm{s}$ per $\mathrm{m}$ test at the location of the removed fence showed first damage. At the end of the $10 \mathrm{l} / \mathrm{s}$ per test the damage on the slope developed downward to the berm, ripping off a 0.05 to $0.1 \mathrm{~m}$ thick layer of the grass cover (Figure 11). The damage at the berm evolved in the same way.

At 4 hours after the start of the test with 30 1/s per m, with a high overtopping wave some bricks were displaced (Figure 12). The rate increased rapidly. In 1 hour a total of 54 bricks were washed out. At the same time the erosion hole just in front of the curb expanded and deepened. At each following wave water was pressed underneath the concrete band causing upward forces on the bricks of the parking lot. Together with the uplift forces during over wash of the overtopping waves a first brick of the parking lot came out. This damage expanded fast. After 4 hours and 20 minutes the test was stopped because of the large damages (figure 13).

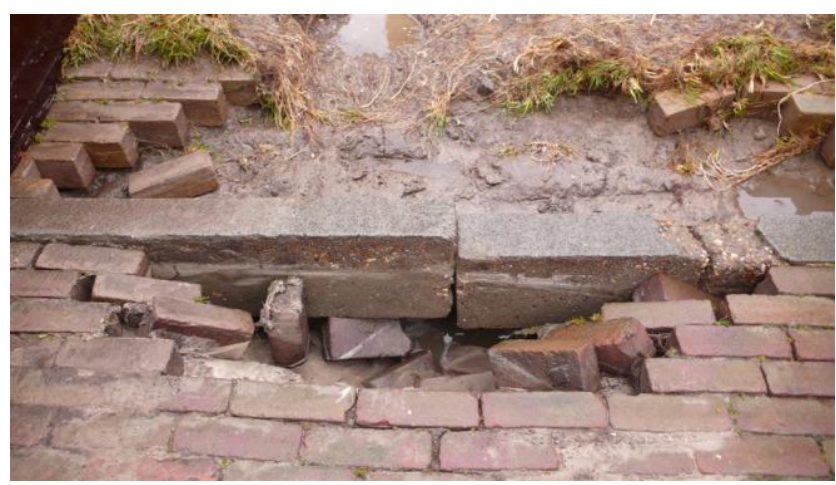

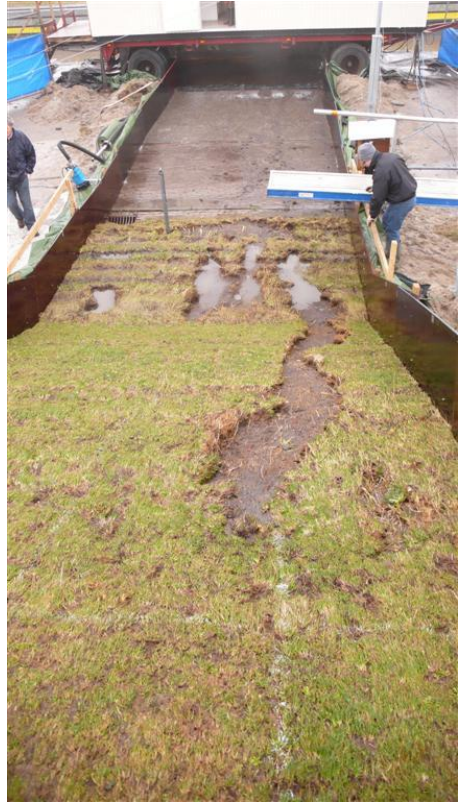

Figure 11. Damage section A2 after 6 hours $10 \mathrm{l} / \mathrm{s}$ per $\mathrm{m}$

Figure 12. After 4 hours $30 \mathrm{l} / \mathrm{s}$ per some bricks of the parking lot were removed
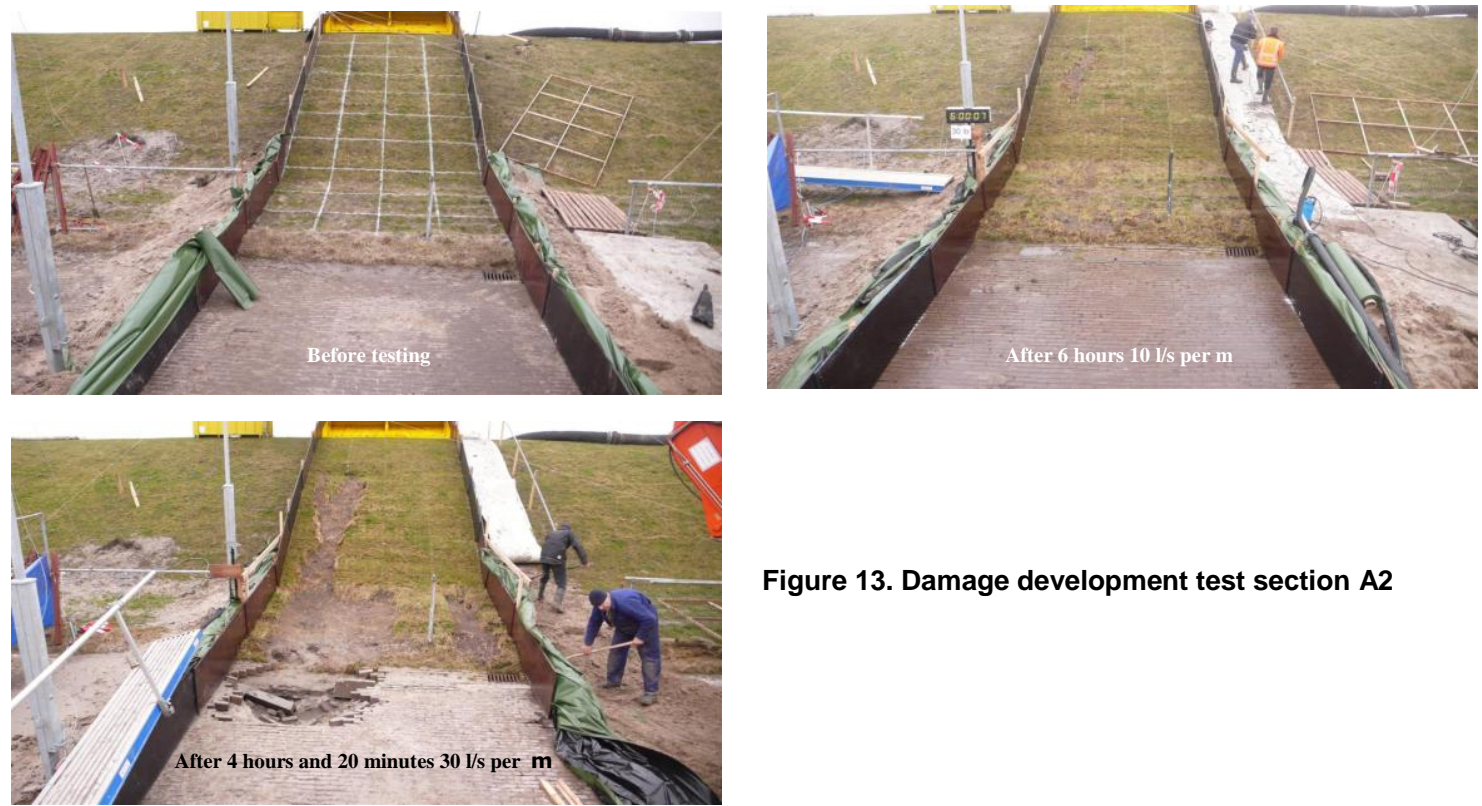

Figure 13. Damage development test section A2

\section{Test (Afsluitdijk) A3: Concrete stair case on a grass covered slope}

The stairs had a width of $1 \mathrm{~m}$ and was constructed with prefab elements $(0.38 \mathrm{~m}$ wide and $0.15 \mathrm{~m}$ high). On both sides of the staircase a row of tiles were present. The staircase as well as the tiles was constructed directly on bare clay. Just beneath the staircase a small horizontal path was present, consisting of small bricks, funded on a small layer of sand on top of a $1.5 \mathrm{~m}$ thick layer of clay.

Results of test series A3. From the start of the test it was clear that concentration of flow occurred on both sides of the staircase. The large volumes with high velocities caused erosion holes just beneath 
the end of the row of tiles. After a while these erosion holes reached the concrete slab placed at the parking lot preventing it to suffer damage (was already subject of investigations in test A2).

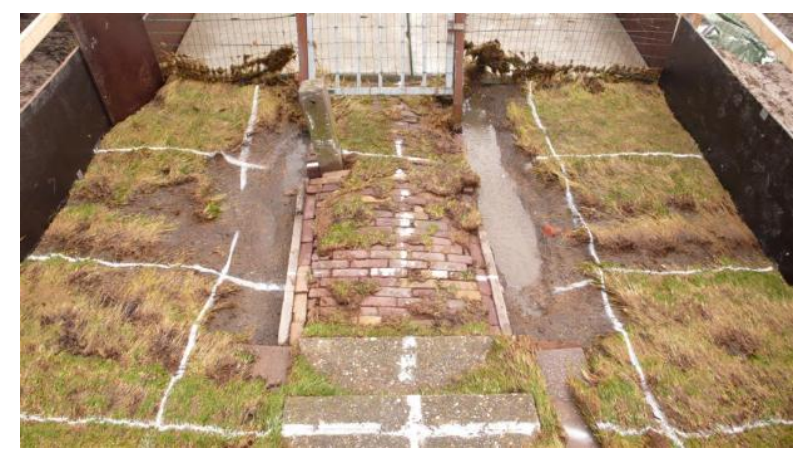

Figure 14. Result after 6 hours of $10 \mathrm{l} / \mathrm{s}$ per $\mathrm{m}$.

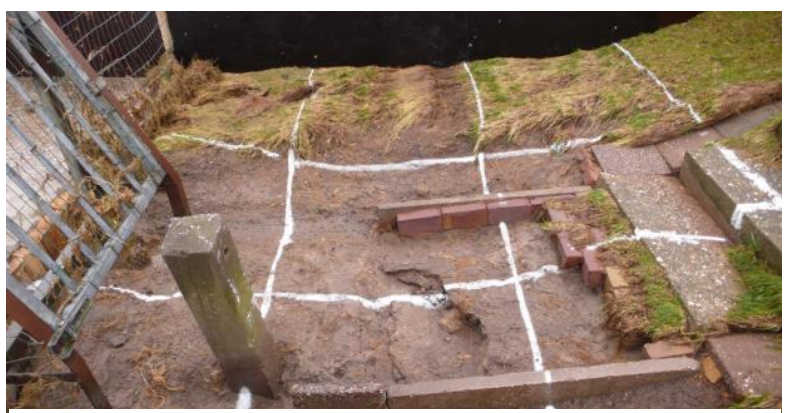

Figure 15. Result after 4 hours of $30 \mathrm{l} / \mathrm{s}$ per $\mathrm{m}$.

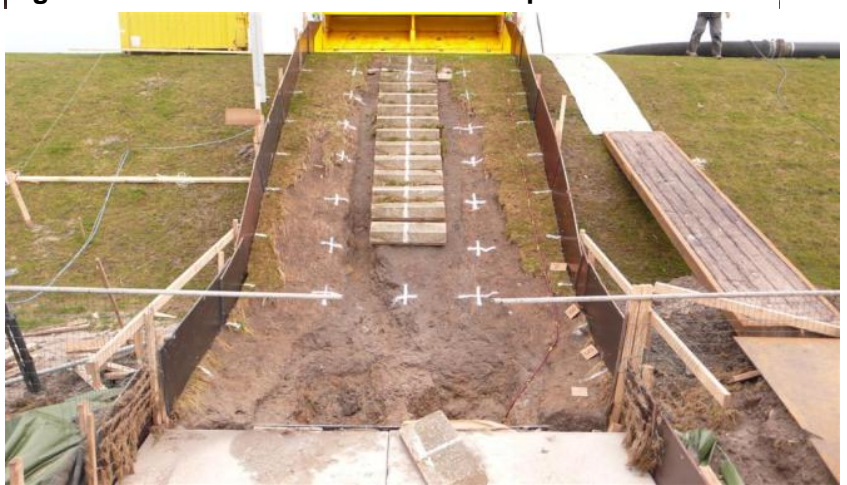

Figure 16. End result test section A3 after 2 hours $75 \mathrm{l} / \mathrm{s}$ per $\mathrm{m}$
In the $10 \mathrm{l} / \mathrm{s}$ per $\mathrm{m}$ test erosion started at the low end of the tiles on both sides of the staircase (Figure 14).

In the $301 / \mathrm{s}$ per $\mathrm{m}$ test more damage occurred at the path. After 4 hours most of the path had disintegrated (Figure 15). The erosion holes at the toe deepened and a initial damage on the slope developed to the toe.

In the last session of the $50 \mathrm{l} / \mathrm{s}$ per $\mathrm{m}$ test almost half of the grass cover was removed from the slope. But again this did not cause ongoing damage. The erosion holes below the staircase developed further in depth and in length.

At $751 / \mathrm{s}$ per the lower 4 steps of the staircase came down. The test was stopped because of this. Very deep holes (over $1 \mathrm{~m}$ ) had developed beneath the staircase (Figure 16). As there was a $1.5 \mathrm{~m}$ thick layer of clay present, the core of the dike was not reached yet and therefore the dike did not fail yet.

\section{Test (Vecht dike) V1: Grass covered slope with a maintenance road crossing}

Test section V1 was situated at the river side of the dike. It contained a crossing of a maintenance road consisting of concrete $40 \mathrm{~cm}$ x $40 \mathrm{~cm}$ x $12 \mathrm{~cm}$ bricks that allow for grass growth. The road crossed the river slope at an angle. The crest was covered with the same concrete bricks. Figure 17 shows a cross section.

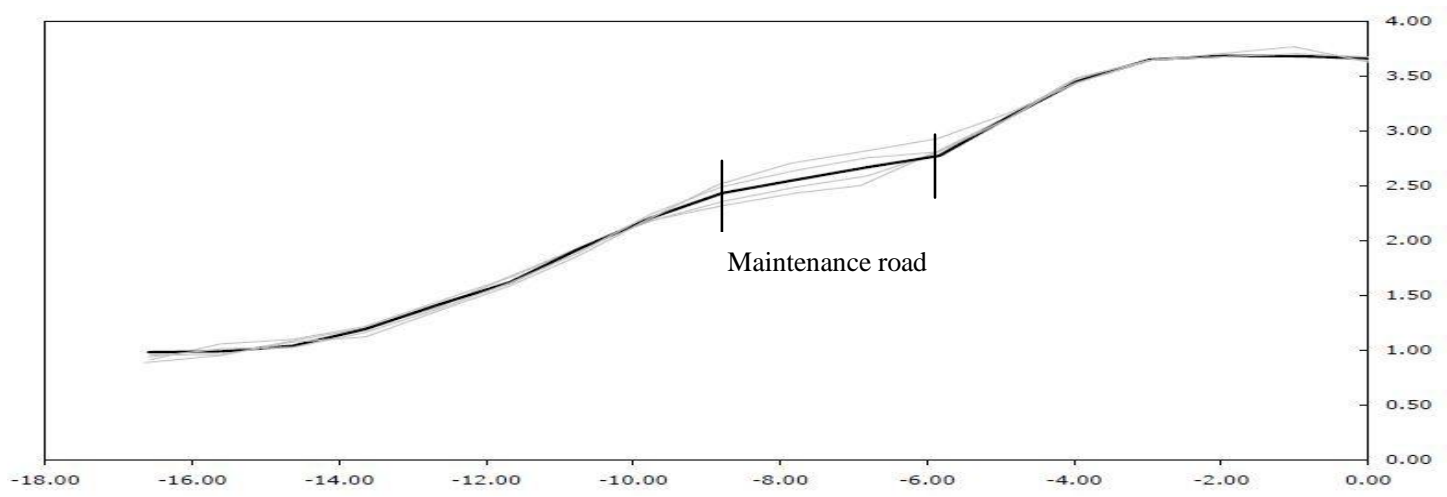

Figure 17. Cross section V1 (measures in meters) 
Just above the maintenance road deep track was present, showing a vertical ridge against the concrete bricks.

Results of test series V1. During the $1 \mathrm{l} / \mathrm{s}$ per $\mathrm{m}$ test initial damage developed at the vertical ridge just above the maintenance road. These damages evolved slowly at $10 \mathrm{l} / \mathrm{s}$ per $\mathrm{m}$ (Figure 18) and at $30 \mathrm{l} / \mathrm{s}$ per $\mathrm{m}$ these damages developed to two substantial holes undermining the road. (Figure 19).

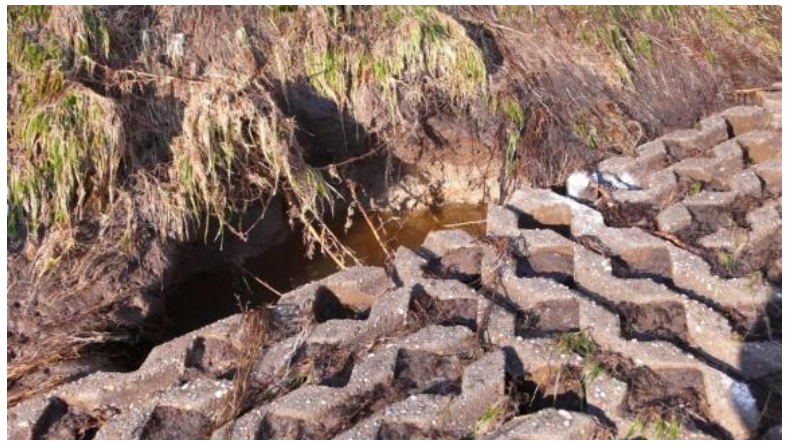

Figure 19. One of the holes undermining the maintenance road

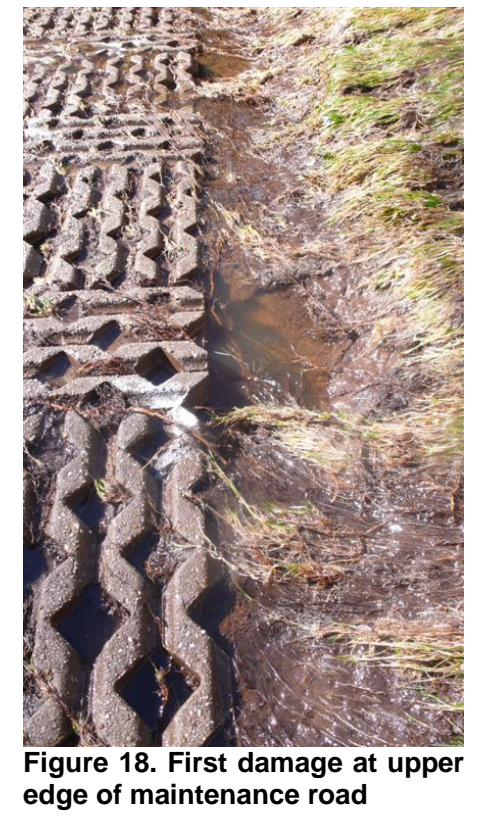

At the start of the $50 \mathrm{l} / \mathrm{s}$ per $\mathrm{m}$ test, with a large wave, bricks came out. The end result is shown in Figure 20. At this time also large surfaces (several square meters) of the grass cover at the toe and the berm were eroded as well.
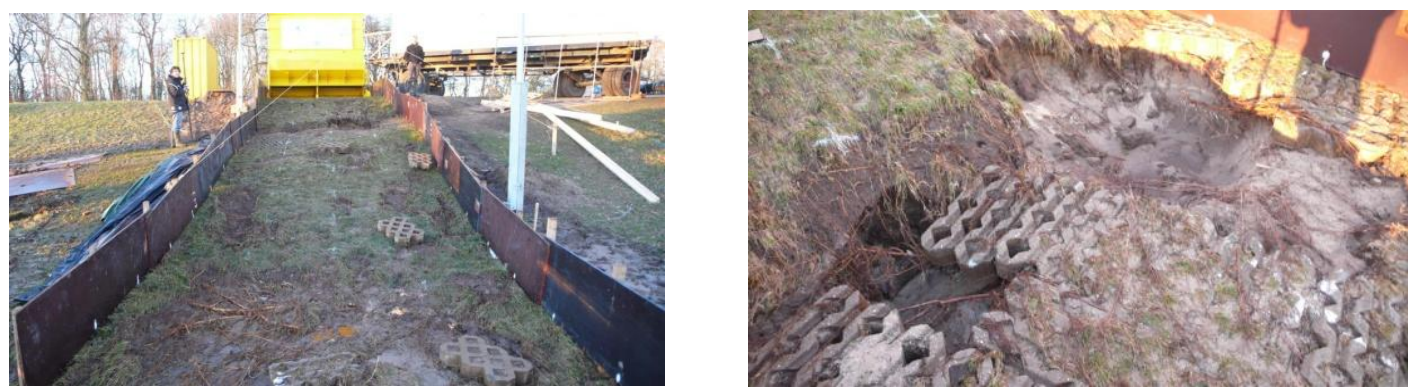

Figure 20. End result test V1

\section{Test (Vecht dike) V2: Grass covered slope with a tree on the berm}

At the second test section at the Vecht dike a large tree (trunk $0.8 \mathrm{~m}$ wide) was present at the toe of the dike (Figure 21). Figure 22 shows a cross section. This cross section shows the slope to be somewhat hollow with the bump marking the position of the tree.

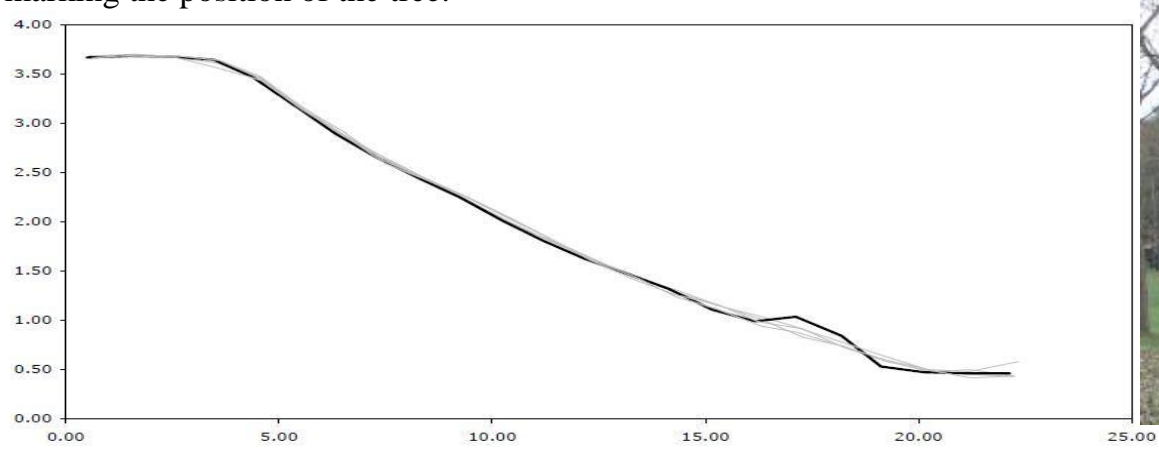

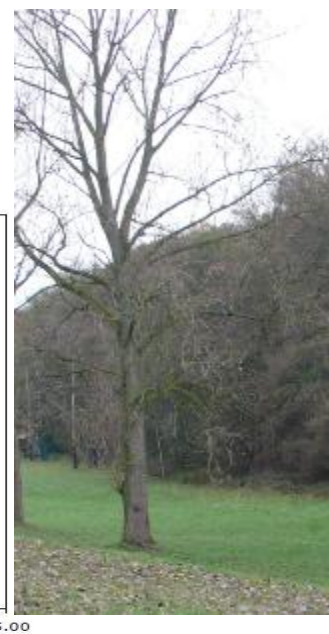

Figure 21. Tree at the landward berm

Figure 22. Cross section V2 (measures in $\mathrm{m}$ )

Results of test series V2. At the 5 1/s per $m$ test the grass cover around the tree disintegrated showing a lot of near surface roots from the tree. The damage developed fast at the $10 \mathrm{l} / \mathrm{s}$ per $\mathrm{m}$ test (Figure 23). 


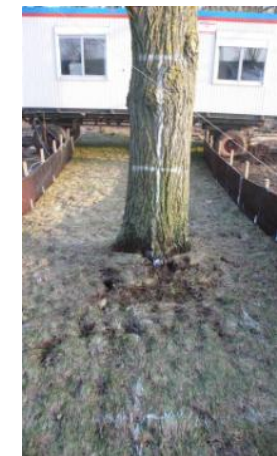

After 2 hours

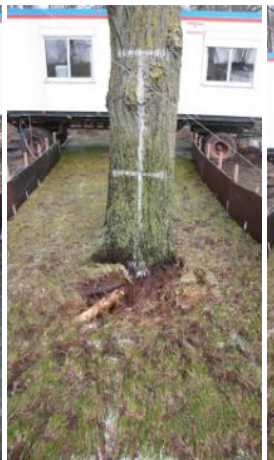

After 4 hours

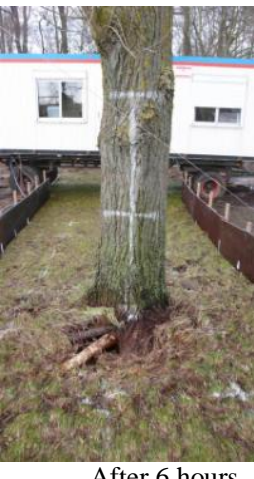

After 6 hours

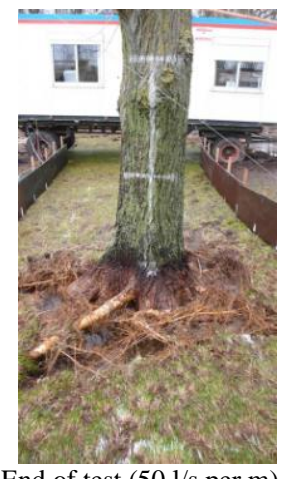

End of test (50 1/s per m)

Figure 23. Damage development section V2 at $10 \mathrm{l} / \mathrm{s}$ per $\mathrm{m}$ and end result after $51 / 2$ hours $50 \mathrm{l} / \mathrm{s}$ per m

In the $30 \mathrm{l} / \mathrm{s}$ per $\mathrm{m}$ test the surface of the slope did not change much. The damage at the tree increased. In the next test $(50 \mathrm{l} / \mathrm{s}$ per $\mathrm{m})$ the damage at the tree expanded to over $4 \mathrm{~m}^{2}$ and sand was washed out. The test was stopped after $5 \frac{1 / 2}{2}$ hours; the dike at the tree was considered to have failed (Figure 23 on the right).

\section{Test (Vecht dike) V3: Grass covered slope with loads induced by wave climate with $\mathbf{H}_{\mathrm{s}}=\mathbf{1} \mathrm{m}$}

All of the previous tests from 2007 to now were performed with a wave climate causing overtopping waves with a significant wave height of $2 \mathrm{~m}$. To investigate the influence of the wave climate on the loads on the landward slopes now the significant wave height was lowered to $1 \mathrm{~m}$ representing wave overtopping conditions at a river dike. The mean overtopping discharges were not changed resulting in more waves overtopping but with less individual wave volume.

As the test location was just next to section V2 the appearance of this test lane was similar. The vegetation was homogeneous with grass and moss. The surface again was irregular because of the frequent mole activities.

Results of test series V3. The behaviour of the slope was similar to the previous test at section V2. At $30 \mathrm{l} / \mathrm{s}$ per $\mathrm{m}$ things started to happen. The small holes on the surface eroded at large waves. All of the damages started where signs of activities of moles were found. In Figure 24 the damages after 30 1/s per $m$ are shown.

In the next test with $50 \mathrm{l} / \mathrm{s}$ per $\mathrm{m}$ the damages increased fast. At a mole hole which penetrated the top layer to the sand core of the dike the damage was ongoing in depth, first undermining the grass cover and top layer and next resulting in collapse of the top layer. The magnitude of the damages is shown in Figure 25.

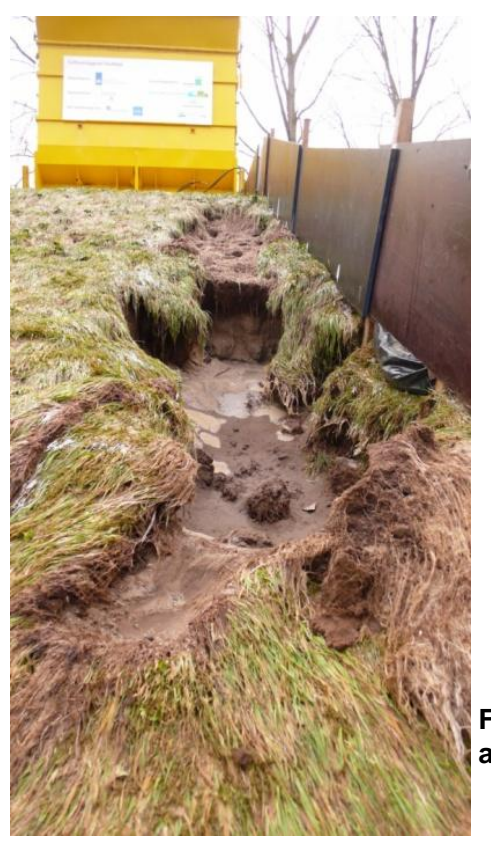

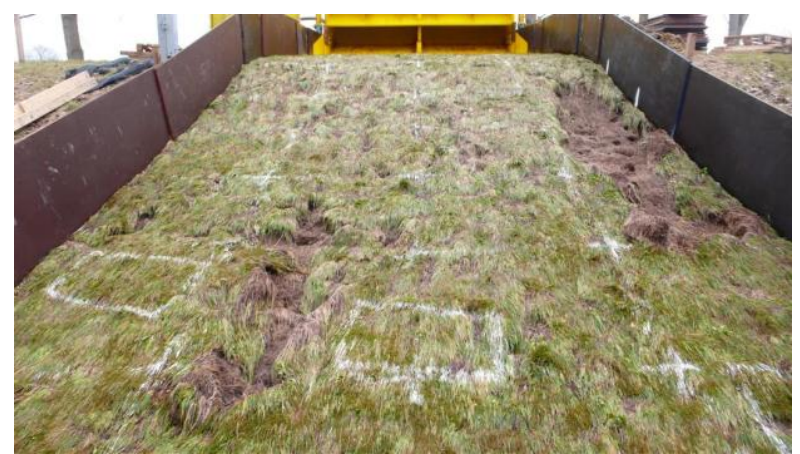

Figure 24. Damage section V3 after test session $30 \mathrm{l} / \mathrm{s}$ per $\mathrm{m}$ 
Test (Vecht dike) V4: Grass covered slope with loads induced by wave climate with $\mathbf{H}_{\mathbf{s}}=\mathbf{3} \mathbf{~ m}$

To test the influence of a large wave height as overtopping condition, resulting in the same mean overtopping discharges, also a test has been performed with $\mathrm{H}_{\mathrm{s}}=3 \mathrm{~m}$. This means a smaller number of overtopping waves, but each wave contained a larger volume of overtopping water.

This test section had again an appearance similar to sections 2 and 3. A lot of mole activity and a somewhat hollow slope were observed. Also the transition to the berm was rounded.

Results of test series V4. From the start of the test series it was observed that the larger overtopping wave volumes had an immediate impact on initiation and development of damage at the slope. This damage development appeared to be the same as with test series V2 (on the slope) and V3, but much faster. Already at $5 \mathrm{l} / \mathrm{s}$ per $\mathrm{m}$ several initial damages on the slope developed to gullies. To the end of this test some of the gullies merged but did not change much in depth. At $10 \mathrm{l} / \mathrm{s}$ per m, locally the depth increased to $35 \mathrm{~cm}$ revealing the sand of the core. All of these local deep marks were mole tunnel induced holes. The $30 \mathrm{l} / \mathrm{s}$ per $\mathrm{m}$ test was stopped after one hour (Figure 26). The core material was washed out, leading to head cut erosion. Also higher on the slope a hole was found which would have led to dike failure if the test had not been stopped.
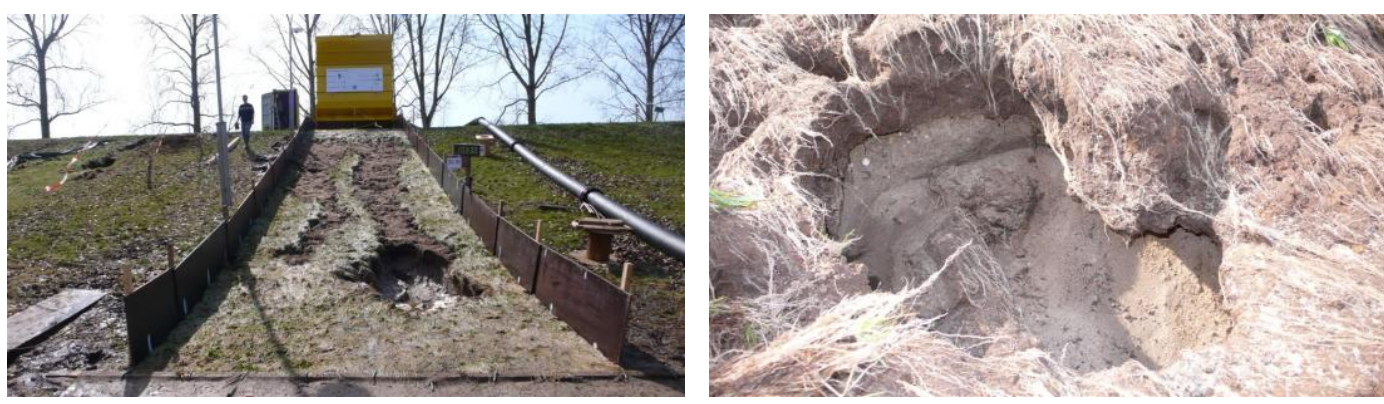

Figure 26. End result section V4 after 1 hour $30 \mathrm{l} / \mathrm{s}$ per $\mathrm{m}$

\section{OBSERVATIONS AND RECOMMANDATIONS}

The tests with the Wave Overtopping Simulator show significant resistance of the grass cover against erosion of overtopping water. It was observed that small overtopping volumes have no effect, but wear out very slowly some bold spots. Larger volumes are able to get a grip on the sod potentially creating initial damages (about $1 \mathrm{dm}^{2}$ ) and ripping off the grass cover $(5-15 \mathrm{~cm})$.

One important finding from the tests is this damage to the grass sod (ripping off) does not directly mean that the top layer of the grass cover (roughly $20 \mathrm{~cm}$ thick) in total will fail. The clay at the Afsluitdijk was not determined to be erosion resistant and the cover layer at the Vecht dike consisted for $90 \%$ of sand. How was it possible that non erosion resistant cover layers actually proved to be very erosion resistant?

The explanation might be that roots in the top layer go deeper than the grass sod that was ripped off and that what remained was not a bare clay layer (which indeed is much less erosion resistant than grass, see Steendam et al., 2008), but a layer with roots. The roots may have the ability to "cement" the clay together by chemical reaction. And this may change the properties or behaviour of the clay to erosion drastically. The $90 \%$ sand cover layer became an erosion resistant layer. It was very thin and placed directly on sand and that caused the early failures at the Vecht dike.

This cementing of sand by roots and/ or other light bonding mechanisms, is known, but much more research is needed to describe and measure this feature in a way that it can indeed be detected and used in modelling the strength of grassed inner slopes of dikes by wave overtopping.

Sharp transitions from slope to berm turned out to be a weak spot. This also was seen in all previous tests with the Wave Overtopping Simulator (Akkerman, 2007, Steendam, 2008, Van der Meer 2009). A more gentle transition like at sections 2 to 4 at the Vecht dike causes better direction guidance of the flow, thus resulting in less damage.

The bulging mechanism found in previous tests (Steendam et al, 2008) at which about one square meter of the grass cover first lifted and then with a large wave was washed off, was not seen in the current tests. The reason why at certain slopes this mechanism occurs, or why not, is not clear yet. 
Possibly there is a connection with the management of the grass covered slope and the cementing process.

The presence of objects at or in the dike configuration is possible initiators for damage. This initiation of damage may occur for various reasons. The main reason is interference with the flow causing extra erosion forces. This interference may lead to more concentrated flows (section A3 stair case) or blockage of the flow (section V2 tree) causing turbulence.

Also transitions from grass covers to other, hard, covers of the dike are subject to initiation of damage. Here maintenance is a great importance. As soon as the flow gets a grip on the hard elements, turbulence and impulsive forces will lead to undermining and ultimately failure of these element covers (section A2 parking lot and V1 maintenance road). The connection between a grass cover and a hard cover consisting of loose elements has proven to be fragile. How this should or could be handled in design and in maintenance must be subject of further investigations.

Furthermore maintenance near objects is seen to be of great importance. Lack of proper maintenance may lead to weak spots in the cover. In the case of a fence on the berm (test A2 and A3) not only the fence itself caused damage (test A3; the fence was removed during test A2). The appearance of the local grass cover showed lack of maintenance (cutting the grass near the fence is difficult). The grass was longer and over time a ridge had been built up. The ridge created a habitat for a lot of species like mice, which created an easy to erode heap and therefore potential initiator for damage. In management and maintenance programs special care has to be taken at objects on or near the dike. The grass cover has to be as smooth as possible around the objects, interfering as little as possible the flow. Again a suitable connection between the objects and the grass cover, to resist initiation of damage should be subject of further investigations.

From tests with moderate and severe hydraulic overtopping regimes (mean discharge stayed the same) show indeed that large individual overtopping wave volumes are causing the initiation and expansion of damages. A great number of small overtopping wave volumes will not cause severe damage as a few large volumes may. There seems to be a threshold for which overtopping volumes does not affect the erodibility of the grass cover. Above this threshold larger waves have a larger impact on the initiation and expansion of damages than smaller waves. This theory has fully been analyzed in Van der Meer et al., 2010, leading to the cumulative overtopping load with a critical velocity as offset where damage may start.

The results of all tests performed from 2007 to 2010, together with further research within the program, will finally lead to a Technical Report and new guidelines for safety assessments against wave overtopping.

\section{ACKNOWLEDGEMENTS}

All Dutch tests with the Wave Overtopping Simulator were conducted under the SBW-project (Strength and Loads on Water Defences) of the Ministry of Transport, Public Works and Water Management, Rijkswaterstaat. The project is managed by Deltares.

\section{REFERENCES}

Akkerman, G.J., P. Bernardini, J.W. van der Meer, H. Verheij and A. van Hoven. 2007. Field tests on sea defences subject to wave overtopping. Proceedings of Coastal Structures Conference. Venice.

Deltares. 2009. Factual report grondonderzoek Afsluitdijk, 1001189-010-GEO-0001. In Dutch.

Deltares, 2009. Factual report monitoring Afsluitdijk, 1200259-001-GEO-0002. In Dutch.

Ooij, J. and T. Hull. 2009. Golfoverslag en sterkte grasbekleding op dijken, deel 1 en 2. In Dutch

Steendam, G.J., J.W. van der Meer, G. de Raat, W. de Vries and J.Y. Frissel. 2008. Influence of Management and Maintenance on erosive impact of wave overtopping on grass covered slopes of dikes. International Symposium on Floodrisk. Oxford.

Van der Meer, J.W., W. Snijders and E. Regeling. 2006. The wave overtopping simulator. Proceedings International Conference on Coastal Engineering. ASCE. San Diego.

Van der Meer, J.W., P. Bernardini, G.J. Steendam, G.J. Akkerman and G.J.C.M. Hoffmans. 2007. The wave overtopping simulator in action. Proceedings Coastal Structures Conference. Venice. 
Van der Meer J.W., G.J. Steendam, G. de Raat and P. Bernadini. 2008. Further developments on the wave overtopping simulator. ASCE. Proceedings International Conference on Coastal Engineering. ASCE. Hamburg.

Van der Meer, J.W., R. Schrijver, B. Hardeman, A. van Hoven, H. Verheij and G.J. Steendam. 2009. Guidance on erosion resistance of inner slopes of dikes from three years of testing with the Wave Overtopping Simulator. Proc. ICE, Breakwaters, Marine Structures an Coastlines. Edinburgh.

Van der Meer, J.W., B. Hardeman, G.J. Steendam, H. Schüttrumpf and H. Verheij, 2010, Flow depths and velocities at crest and landward slope of a dike, in theory and with the wave overtopping simulator. Proceedings International Conference on Coastal Engineering. ASCE. Shanghai. 